\title{
ASPEK DIKSI SERTA NILAI-NILAI PENDIDIKAN KARAKTER DALAM NOVEL AYAH KARYA ANDREA HIRATA
}

\author{
Annis Kurniyati Rizqi, Sarwiji Suwandi, Raheni Suhita \\ Universitas Sebelas Maret \\ Surel: annis21@ student.uns.ac.id.
}

\begin{abstract}
This study aimed to describe and explain: (1) the aspects of diction used in the novel Ayah by Andrea Hirata; (2) the values of character education in the novel Ayah by Andrea Hirata; and (3) the relevance of Andrea Hirata's novel Ayah as a teaching material of language and literature in Vocational High School. This study is a qualitative research that analyzes the data in the form of documents with the object of study of novel Ayah by Andrea Hirata. The results of this study are as follows. (1) The diction aspect contained in Andrea Hirata's father's novel includes five types of diction, (2) Novels contain sixteen points of character education values, (3) Novel Ayah is relevant to the learning of Indonesian language and literature in SMK because the aspect of diction and the value of character education in accordance with the learning objectives that have been designed using the Learning Implementation Plan based on the Core Competence and Basic Competence which includes the competencies that the learners must achieve in language and literature learning. Dad's novel can increase students' vocabulary mastery according to language ability, student psychology, and cultural background.
\end{abstract}

Keywords: dictions, educations, characters, learning, literature

\begin{abstract}
Abstrak: Penelitian ini bertujuan untuk mendeskripsikan: (1) aspek diksi dalam novel Ayah karya Andrea Hirata; (2) nilai-nilai pendidikan karakter yang terkandung dalam novel Ayah karya Andrea Hirata; (3) relevansi aspek diksi dan nilai-nilai pendidikan karakter dalam novel Ayah karya Andrea Hirata dengan pembelajaran bahasa dan sastra Indonesia di SMK. Penelitian ini merupakan penelitian kualitatif yang menganalisis data berupa dokumen dengan objek kajian novel Ayah. Hasil dari penelitian ini (1) aspek diksi yang terdapat dalam novel Ayah karya Andrea Hirata meliputi lima jenis diksi, (2) novel Ayah mengandung enam belas poin nilai-nilai pendidikan karakter, (3) novel Ayah relevan dengan pembelajaran bahasa dan sastra Indonesia di SMK karena aspek diksi dan nilai pendidikan karakter yang sesuai dengan tujuan pembelajaran yang telah dirancang menggunakan Rencana Pelaksanaan Pembelajaran yang didasari adanya Kompetensi Inti dan Kompetensi Dasar yang mencantumkan kompetensi yang harus dicapai peserta didik dalam pembelajaran bahasa dan sastra. Novel Ayah dapat meningkatkan penguasaan kosakata peserta didik sesuai dengan kemampuan bahasa, psikologi siswa, dan latar belakang budayanya.
\end{abstract}

Kata kunci: diksi, pendidikan, karakter, pembelajaran, sastra 


\section{PENDAHULUAN}

Novel termasuk dalam karya sastra dengan genre fiksi yang dikenal dengan istilah prosa fiksi. Penyajian suatu cerita dengan lebih rinci yang melibatkan permasalahan yang kompleks disebabkan oleh unsur-unsur pembangun novel. Selain aspek-aspek tersebut, kriteria novel yang baik dapat ditandai dengan penggunaan bahasa yang mudah dipahami. Bahasa yang dimaksudkan dalam konteks ini tentunya bahasa sastra. Bahasa yang digunakan pengarang untuk menunjukkan nada (tone) dan sikap terhadap karya yang diciptakan.

Sastra harus dibedakan dengan karya yang bukan sastra. Variabel kontrolnya adalha bagasa sebagai alat untuk menghasilkan karya. Bahasa sastra bersifat ekspresif sedangkan bahasa ilmiah bersifat logis. Ekspresif yang dimaksudkan adalah ungkapan-ungkapan yang bersifat individual dan subjektif. Bahasa dalam karya sastra bersifat literariness yaitu selain berfungsi estetis juga difungsikan sebagai penyampai pesan. Karya sastra prosa ada yang menyebut dengan fiksi atau cerita rekaan. Prosa atau fiksi adalah kisah atau cerita yang dikembangkan oleh pelaku-pelaku tertentu dengan pemeran, tahapan dan rangkaian cerita tertentu yang bertolak dari hasil imajinasi pengarangnya sehingga menjalin suatu cerita (Aminuddin, 2002 dalam Emzir \& Rohman, 2015: 8,254). Selain berfungsi ekspresif, ciri khas bahasa yang mudah dipahami apabila penggunaan pilihan kata atau diksi yang tepat dan sesuai. Aspek ketepatan, kebenaran dan kesesuaian pilihan kata sangat diperhatikan yang disesuaikan dengan konteks dan situasi yang digunakan. Keragaman serta variasi pilihan kata yang digunakan pengarang mencerminkan tingkatan intelektualitas bahasa yang dikuasai. Kekayaan diksi yang digunakan dapat ditunjukkan dengan termuatnya nilai-nilai pendidikan karakter dalam novel. Sebagai contohnya nilai kesantunan dapat dimunculkan melalui pilihan kata yang memiliki nilai rasa yang positif.

Pendapat Ismawati menyatakan bahwa karakter sangat erat dengan sikap dan pilihan cara bertindak (2013: 115). Pentingnya karakter yang dibiasakan saat ini akan menentukan karakter bangsa pada masa yang akan datang. Karakter dimaknai sebagai cara berpikir dan berperilaku yang khas tiap individu untuk 
hidup dan bekerja sama, baik dalam lingkup keluarga, masyarakat, bangsa, dan negara. Karya Andrea Hirata tidak pernah lepas dari muatan pendidikan karakter yang dapat ditelaah lebih dalam. Hal ini sejalan dengan fungsi pengajaran sastra yang dapat membantu pendidikan secara utuh apabila cakupannya meliputi 4 manfaat, yaitu: membantu keterampilan berbahasa, meningkatkan pengetahuan budaya, mengembangkan cipta dan rasa, serta menunjang pembentukan watak siswa.

Saat ini pendidikan karakter tengah digencarkan implementasinya oleh pemerintah mulai dari jenjang pendidikan tingkat TK, SD, SMP maupun SMA/SMK/MA bahkan Perguruan Tinggi. Nilai-nilai pendidikan berkorelasi dengan pendidikan karakter yang relevan dengan pembelajaran bahasa dan sastra di sekolah. Pendidikan karakter dimaknai sebagai pendidikan nilai, pendidikan budi pekerti, pendidikan moral, pendidikan watak, yang bertujuan mengembangkan kemampuan peserta didik untuk memberikan keputusan baikburuk. Peneliti tertarik untuk menganalisis novel Ayah dengan batasan dan fokus penelitian pada aspek-aspek penggunaan diksi serta muatan nilai-nilai pendidikan karakter. Hasil penelitian ini kemudian dikaitkan dengan relevansinya dengan pembelajaran Bahasa Indonesia pada tingkat SMA/SMK/MA. Terlebih muatan nilai pendidikan karakter kerja keras yang cocok untuk siswa di bangku SMK.

Pengertian dari pengajaran sastra adalah pengajaran yang menyangkut seluruh aspek sastra, yang meliputi: Teori Sastra, Sejarah Sastra, Kritik Sastra, Sastra Perbandingan, dan Apresiasi Sastra. Kegiatan apresiasi merujuk pada aspek afektif yang berkaitan dengan rasa, nilai-nilai, dan nurani. Tujuan jangka panjang pengajaran sastra adalah terbentuknya sikap positif terhadap sastra dengan ciri siswa mempunyai apresiasi yang tinggi terhadap karya sastra (Ismawati, 2013: 30). Pada dasarnya, strategi dalam pengajaran cerpen maupun novel bisa ditentukan oleh guru sendiri berdasarkan kebutuhan situasi yang ada. Kegiatan persiapan yang dilakukan yaitu dengan guru memilih bahan yang akan diapreasiasikan. Setelah menentukan bahan, guru melakukan apersepsi serta memberi pengatntar tentang pembelajaran yang akan dilaksanakan. Tahap selanjutnya yaitu penyajian. Hal yang pertama kali dilakukan guru pada saat 
penyajian adalah guru mengajak siswa membaca, kemudian guru bertanya tentang pemahaman novel dalam bentuk diskusi kelas. Tahap terakhir yaitu penguatan (refleksi) yang disertai dengan nilai pendidikan yang termuat dalam karya sastra.

Penelitian ini mengacu pada tiga rumusan masalah, yaitu: 1) Bagaimanakah pemanfaatan diksi yang digunakan oleh Andrea Hirata dalam novel Ayah?; 2) Apa sajakah nilai-nilai pendidikan karakter yang ingin disampaikan oleh Andrea Hirata dalam novel Ayah?; dan 3) Bagaimanakah relevansi aspek diksi serta nilai pendidikan karakter dalam novel Ayah karya Andrea Hirata dengan pembelajaran bahasa Indonesia?

Adapun tujuan penelitian ini yaitu (1) untuk mendeskripsikan dan menjelaskan pemnafaatan diksi yang digunakan oleh Andrea Hirata dalam novel Ayah; (2) untuk mendeskripsikan dan menjelaskan nilai-niai pendidikan karakter yang ingin disampaikan oleh Andrea Hirata dalam novel Ayah; dan (3) untuk mendeskripsikan dan menjelaskan relevansi aspek diksi serta nilai pendidikan karakter dalam novel Ayah karya Andrea Hirata dengan pembelajarna Bahasa Indonesia di SMK.

Tidak semua orang pandai memilih kata-kata yang tepat, lengkap, dan sesuai yang dapat mencerminkan pikiran dan perasaan yang sesungguhnya. Selain itu, sebuah perkataan belum tentu memiliki makna yang sama bagi semua orang. Maka dalam komunikasi diperlukan pilihan kata atau diksi yang tepat agar pesan atau informasi yang ingin disampaikan dapat diterima secara benar dan efektif (Irfariati, 2017:42). Adapun mengenai kriteria diksi yang baik apabila dilakukan secara efektif dan tepat di dalam makna, sesuai dengan pembahasan, pendengar maupun konteks situasi dan kondisi. Keraf, (2007:24) memberikan intisari pembahasan diksi yakni:

(1) Diksi mencakup pengertian kata-kata mana yang dipakai untuk menyampaikan suatu gagasan, bagaimana membentuk pengelompokan kata-kata yang tepat atau menggunakan ungkapan-ungkapan yang tepat, dan gaya mana yang baik digunakan dalam situasi; (2) diksi adalah kemampuan membedakan secara tepat nuansa-nuansa makna dari gagasan yang ingin disampaikan, dan disesuaikan dengan situasi dan nilai rasa yang dimiiki kelompok masyarakat pendengar; dan (3) pilihan kata yang tepat dan sesuai hanya dimungkinkan oleh penguasaan sejumlah besar kosa kata atau perbendaharaan kata bahasa itu. 
Pilihan kata-kata yang digunakan pengarang dalam karyanya menunjukkan kemampuan dalam mengolah kata. Istilah diksi atau yang dikenal dengan pilihan kata yang digunakan oleh pengarang untuk memberikan efek tertentu. Sedikit menyinggung tentang style, stail atau gaya yaitu cara yang khas dipergunakan oleh seseorang untuk mengutarakan atau mengungkapkan diri gaya pribadi. Cara pengungkapan tersebut bisa meliputi setiap aspek kebahasaan: diksi, penggunaan bahasa kias, bahasa figuratif, struktur kalimat, bentuk-bentuk wacana, dan sarana retorika yang lain (Satoto, 2012:35). Gaya bahasa sebagai bagian dari diksi bertalian dengan ungkapan-ungkapan individual atau karakteristik, atau yang memiliki nilai artistik yang tinggi (Keraf, 2007: 24). The diction of his tales is fatfree, artistic and facile. The unique power of using words approtiately in this stories gives him a special ability to discover the inner strength of the words (Sarker, 2016). Salah satu bentuk penggunaan diksi yang tepat dapat menciptakan kekuatan kata dengan bentuk yang unik. Tegasnya penguasaan kosa kata yang luas akan mendorong pada kemampuan yang tinggi untuk memilih kata yang paling tepat dan harmonis untuk mewakili maksud atau gagasannya.

Pendidikan karakter bertujuan untuk meningkatkan mutu proses dan hasil pendidikan yang mengarah pada pembentukan karakter dan akhlak mulia peserta didik secara utuh, terpadu, dan seimbang, sesuai dengan standar kompetensi lulusan pada setiap satuan pendidikan. Melalui pendidikan karakter peserta didik diharapkan mampu secara mandiri meningkatkan dan menggunakan pengetahuannya, mengkaji dan menginternalisasikan serta mempersonalisasikan nilai-nilai karakter dan akhlak mulia sehingga terwujud dalam perilaku seharihari. Pembangunan karakter dapat diterapkan melalui sosialisasi, pendidikan dan pembelajaran, pemberdayaan, pembudayaan dan kerja sama seluruh komponen bangsa dan negara. Peran pendidikan sangat strategis sebagai pembangun integrasi nasional yang kuat. Selain dipengaruhi faktor politik, ekonomi, pendidikan juga berkaitan dengan sosial dan budaya sebagai pembangun ketahanan nasional. Selain itu, hal ini disempurnakan dengan Peraturan Presiden 
Repulik Indonesia Nomor 87 Tahun 2017 tentang Penguatan Pendidikan Karakter pada pasal 3 berbunyi

PPK dilaksanakan dengan menerapkan nilai-nilai Pancasila dalam pendidikan karakter, terutama meliputi nilai-nilai religius, jujur, toleran, disiplin, bekerja keras, kreatif, mandiri, demokratis, rasa ingin tahu, semangat kebangsaan, cinta tanah air, menghargai prestasi, komunikatif, cinta damai, gemar membaca, peduli lingkungan, peduli sosial, dan bertanggung jawab.

secara lebih jelasnya pengertian nilai-nilai luhur pendidikan karakter yang dapat diterapkan pada peserta didik sebagai berikut.

Tabel 1. 18 Butir Nilai Pendidikan Karakter

\begin{tabular}{|c|c|c|}
\hline No & Nilai & Definisi \\
\hline 1 & Religius & $\begin{array}{l}\text { Sikap dan perilaku yang patuh dalam } \\
\text { melaksanakan ajaran agama yang dianutnya, } \\
\text { toleran terhadap pelaksanaan ibadah agama } \\
\text { lain, dan hidup rukun dengan pemeluk } \\
\text { agama lain. }\end{array}$ \\
\hline 2 & Jujur & $\begin{array}{l}\text { Perilaku yang didasarkan pada upaya } \\
\text { menjadikan dirinya sebagai orang yang } \\
\text { selalu dapat dipercaya, dalam perkataan, } \\
\text { tindakan, dan perbuatan. }\end{array}$ \\
\hline 3 & Toleransi & $\begin{array}{l}\text { Sikap dan tindakan menghargai perbedaan } \\
\text { agama, suku, etnis, pendapat, sikap, dan } \\
\text { tindakan orang lain yang berbeda dari } \\
\text { dirinya. }\end{array}$ \\
\hline 4 & Disiplin & $\begin{array}{l}\text { Tindakan yang menunjukkan perilaku tertib } \\
\text { dan patuh pada berbagai ketentuan dan } \\
\text { peraturan. }\end{array}$ \\
\hline 5 & Kerja keras & $\begin{array}{l}\text { Perilaku yang menunjukkan upaya sungguh- } \\
\text { sungguh dalam mengatasi berbagai } \\
\text { hambatan belajar dan tugas, serta } \\
\text { menyelesaikan tugas dengan sebaik-baiknya. }\end{array}$ \\
\hline 6 & Kreatif & $\begin{array}{l}\text { Berpikir dan melakukan sesuatu untuk } \\
\text { menghasilkan cara atau hasil baru dari } \\
\text { sesuatu yang telah dimiliki. }\end{array}$ \\
\hline 7 & Mandiri & $\begin{array}{l}\text { Sikap dan perilaku yang tidak mudah } \\
\text { tergantung pada orang lain } \\
\text { menyelesaikan tugas-tugas. }\end{array}$ \\
\hline 8 & Demokratis & $\begin{array}{l}\text { Cara berpikir, bersikap, dan bertindak yang } \\
\text { menilai sama hak dan kewajiban dirinya dan } \\
\text { orang lain. }\end{array}$ \\
\hline 9 & Rasa Ingin Tahu & Sikap dan tindakan yang selalu berupaya \\
\hline
\end{tabular}




\begin{tabular}{|c|c|c|}
\hline & & $\begin{array}{l}\text { untuk mengetahui lebih mendalam dan } \\
\text { meluas dari sesuatu yang dipelajarinya, } \\
\text { dilihat, dan didengar. }\end{array}$ \\
\hline 10 & Semangat Kebangsaan & $\begin{array}{l}\text { Cara berpikir, bertindak, dan berwawasan } \\
\text { yang menempatkan kepentingan bangsa dan } \\
\text { negara di atas kepentingan diri dan } \\
\text { kelompoknya. }\end{array}$ \\
\hline 11 & Cinta Tanah Air & $\begin{array}{l}\text { Cara berpikir, bersikap, dan berbuat yang } \\
\text { menunjukkan kesetiaan, kepedulian, dan } \\
\text { penghargaan yang tinggi terhadap bahasa, } \\
\text { lingkungan fisik, sosial, budaya, ekonomi, } \\
\text { dan politik bangsa. }\end{array}$ \\
\hline 12 & Menghargai Prestasi & $\begin{array}{l}\text { Sikap dan tindakan yang mendorong dirinya } \\
\text { untuk menghasilkan sesuatu yang berguna } \\
\text { bagi masyarakat, dan mengakui, serta } \\
\text { menghormati keberhasilan orang lain. }\end{array}$ \\
\hline 13 & $\begin{array}{l}\text { Bersahabat atau } \\
\text { Komunikatif }\end{array}$ & $\begin{array}{l}\text { Tindakan yang memperlihatkan rasa senang } \\
\text { berbicara, bergaul, dan bekerja sama dengan } \\
\text { orang lain. }\end{array}$ \\
\hline 14 & Cinta Damai & $\begin{array}{l}\text { Sikap, perkataan, dan tindakan yang } \\
\text { menyebabkan orang lain merasa senang dan } \\
\text { aman atas kehadiran dirinya. }\end{array}$ \\
\hline 15 & Gemar Membaca & $\begin{array}{l}\text { Kebiasaan menyediakan waktu untuk } \\
\text { membaca berbagai bacaan yang memberikan } \\
\text { kebajikan bagi dirinya. }\end{array}$ \\
\hline 16 & Peduli Lingkungan & $\begin{array}{l}\text { Sikap dan tindakan yang selalu berupaya } \\
\text { mencegah kerusakan-kerusakan pada } \\
\text { lingkungan alam di sekitarnya, dan } \\
\text { mengembangkan upaya-upaya untuk } \\
\text { memperbaiki kerusakan alam yang sudah } \\
\text { terjadi. }\end{array}$ \\
\hline 17 & Peduli sosial & $\begin{array}{l}\text { Sikap dan tindakan yang selalu ingin } \\
\text { memberi bantuan pada orang lain dan } \\
\text { masyarakat yang membutuhkan. }\end{array}$ \\
\hline 18 & Tanggung Jawab & $\begin{array}{l}\text { Sikap dan perilaku seseorang untuk } \\
\text { melaksanakan tugas dan kewajibannya, yang } \\
\text { seharusnya dia lakukan terhadap diri sendiri, } \\
\text { masyarakat, lingkungan (alam, sosial dan } \\
\text { budaya), negara dan Tuhan Yang Maha Esa. }\end{array}$ \\
\hline
\end{tabular}

Sumber: (Wibowo, 2013: 83-84)

Nurgiyantoro (2013:434) berpendapat bahwa sastra memiliki peran sebagai salah satu alat pendidikan yang seharusnya dimanfaatkan dalam dunia pendidikan, dapat difokuskan pada peran dalam usaha membentuk dan mengembangkan 
kepribadian anak, peran sebagai character building. Pembentukan karakter ditularkan melalui amanat atau nilai pesan sebuah karya sastra. Pengajaran bahasa merupakan aspek terpenting dari pengajaran sastra sebagai parsial dari pembelajaran komprehensif bahasa dan sastra Indonesia. Pengajaran sastra menanamkan sikap apresiatif dan menghargai karya sastra. Pembelajaran sastra dapat menjadi sarana yang efektif untuk pendidikan karakter dengan nilai-nilai kehidupan yang dijadikan sebagai inspirasi untuk berperilaku positif.

Kompetensi Inti merupakan pedoman yang digunakan untuk mengembangkan Kompetensi Dasar. Supaya lebih jelas, perhatikanlah tabel 2. Berdasarkan pemetaan silabus tersebut, pembelajaran karya sastra novel terdapat di kelas XI semester genap yang meliputi empat kompetensi inti. Kompetensi spiritual, kompetensi sikap, kompetensi pengetahuan, dan kompetensi keterampilan ditanamkan sebagai salah satu penerapan integrasi pendidikan karakter.

Tabel 2. KI dan KD Pembelajaran Bahasa Indonesia Kelas XI SMA/SMK Kurikulum 2013

Kompetensi Inti
1. $\begin{aligned} & \text { Menghayati dan mengamalkan ajaran agama yang } \\ & \text { dianutnya }\end{aligned}$

Menghayati dan mengamalkan perilaku jujur,
disiplin, tanggung jawab, pedui (gotong royong,
kerja sama, tolerans, damai), santun, responsif,
proaktif, dan menunjukkan sikap sebagai bagian
dari solusi atas berbagai permasalahan dalam
berinteraksi secara efektif dengan lingkungan
sosial dan alam serta dalam menempatkan diri
sebagai cerminan bangsa dan pergaulan dunia
Memahami, menerapkan, dan menganalisis
pengetahuan faktual, konseptual, prosedural, dan
metakognitif berdasarkan rasa ingin tahunya
tentang ilmu pengetahuan, teknologi, seni, budaya,
dan humaniora dengan wawasan kemanusiaan,
kebangsaan, kenegaraan, dan peradaban terkait
penyebab fenomena dan kejadian, serta
menerapkan pengetahuan prosedural pada bidang
kajian yang spesifik sesuai dengan bakat dan

Kompetensi Dasar

1.1. Menerima, mensyukuri, menghayati dan mengamalkan anugerah Tuhan berupa bahasa Indonesia dan menggunakannyaa melalui teks novel lisan maupun tulisan

2.2. Menunjukkan perilaku mulia, percaya diri, tanggung jawab, dan santun dalam menggunakan bahasa Indonesia melalui teks novel lisan maupun tulisan

3.11. Menganalisis pesan dari satu buku fiksi yang dibaca;

3.20. Menganalisis pesan dari dua buku fiksi (novel dan buku kumpulan puisi) yang dibaca. 
minatnya untuk memecahkan masalah

4. Mengolah, menalar, dan menyaji dalam ranah konkret dan ranah abstrak terkait dengan pengembangan dari yang dipelajarinya di sekolah secara mandiri, bertindak secara selektif dan kreatif, serta mampu menggunakan metode sesuai kaidah keilmuan
4.11. Menyusun ulasan terhadap pesan dari satu buku fiksi yang dibaca;

4.20. Menyusun ulasan terhadap pesan dari dua buku kumpulan puisi yang dikaitkan dengan situasi kekinian.

Sumber: (Silabus Mata Pelajaran Bahasa Indonesia SMA/MA/SMK/MAK)

Guru dapat mengajarkan pendidikan karakter secara tersurat maupun tersirat menggunakan media novel sebagai materi ajar. Senada dengan hal tersebut, guru sebagai pendidik dituntut untuk lebih kreatif dalam menguasai materi ajar. Selain metode yang menarik, pemilihan materi ajar yang variatif dapat dijadikan sebagai salah satu cara untuk memotivasi siswa dalam menuangkan ide dan imajinasinya. Pembelajara apresiasi sastra dalam tingkatan SMK/SMA bukan berpatokan pada suka atau tidak suka, akan tetapi lebih diarahkan pada keterlibatan observasi yang peka dan kritis terhadap lingkungan dan masyarakat sekitarnya. Novel dapat dijadikan sebagai media pembelajaran yang efektif untuk menyampaikan pesan nilai-nilai pendidikan karakter yang termuat di dalamnya.

\section{METODE PENELITIAN}

Penelitian ini berupa penelitian kualitatif dengan analisis data berupa dokumen dengan objek kajian novel Ayah karya Andrea Hirata. Pendekatan yang digunakan yaitu pendekatan stilistika yang berfokus pada aspek gaya kata (diksi) dalam novel Ayah. Sumber data yang digunakan berupa dokumen dalam bentuk novel dan informan yang meliputi guru, peserta didik SMK, ahli sastra, dan ahli bahasa. Berdasarkan pendapat Sugiyono (2015:300) teknik pengambilan sampel sumber data dengan pertimbangan tertentu. Teknik pengambilan data dalam penelitian ini menggunakan teknik purposive sampling.

Adapun teknik pengumpulan data yaitu dengan analisis isi, wawancara dan pendapat ahli (expert judgment). Uji validitas data yang digunakan adalah triangulasi teori dan triangulasi data. Beberapa pendapat ahli yang digunakan seperti Aminuddin, Keraf, serta pakar Al-Ma'ruf. Namun fokus penelitian ini 
pada satu teori yang digunakan sebagai landasan. Triangulasi data (sumber) didapatkan dari wawancara mendalam dengan informan guru, siswa, ahli bahasa dan ahli sastra. Analisis data yang digunakan yaitu dengan model interaktif yang di dalamnya terdapat empat komponen analisis yakni: pengumpulan data, reduksi data, dan penyajian data, dan penarikan kesimpulan.

\section{HASIL PENELITIAN DAN PEMBAHASAN}

Penggunaan Aspek Diksi dalam Novel Ayah Karya Andrea Hirata

Diksi merupakan bagian kajian dari stilistika yang dikenal dengan gaya kata. Diksi dalam novel dapat dikaji berdasarkan beberapa jenis seperti kata konkret, kata konotatif, kata sapaan atau nama diri, kata dengan objek realitas alam, kata asing, kata serapan, kosakata bahasa daerah dan sebagainya. Penelitian ini berfokus pada jenis diksi kata konotatif, kata konkret, kosakata bahasa daerah, kata serapan, dan kata asing. Pembatasan dilakukan berdasarkan intensitas munculnya data dengan pertimbangan tertentu.

Diksi yang lebih dikenal dengan pilihan kata merupakan alat yang digunakan oleh pengarang untuk mengungkapkan perasaan, ide, gagasan yang dimilikinya sebagai wakil dari ekspresi jiwa pengarang tersebut. Ketepatan penggunaan diksi dapat memberikan gambaran pada pembaca mengenai kejaidan atau peristiwa dalam sebuah cerita. Dalam penelitian ini dikaji jenis-jenis diksi seperti kata konotatif, kata konkret, kosakata bahasa daerah, kata serapan, dan kata asing. Di bawah ini adalah hasil temuan data jenis-jenis diksi dalam novel Ayah karya Andrea Hirata.

\section{Kata konotatif}

Kata konotatif terlepas dari makna harfiahnya dan berdasarkan perasaan dan atau pikiran pengarang. Konotatif mempunyai makna tautan atau mengandung makna konotasi. Menurut Suwandi (2011:99), konotasi adalah kesan-kesan atau asosiasi-asosiasi yang biasanya bersifat emosional dan subjektif. Dengan demikian dapat dinyatakan bahwa makna konotatif muncul sebagai akibat asoiasi perasaan kita terhadap leksem yang kita gunakan. 
Berikut ini adalah hasil temuan data beserta analisis kata konotatif pada novel Ayah karya Andrea Hirata.

Usaha rental musiknya berakhir secara mengerikan karena orang-orang udik dari Belantik, yang... (Ayah, 2015:19).

Kutipan data di atas termasuk jenis kata konotatif karena di dalam kata udik terdapat makna tambahan yang merujuk pada makna kampung, kurang tahu sopan santun, canggung (kaku) tingkah lakunya. Kata tersebut digunakan dengan maksud sebagai bentuk konotatif dari makna kampung. Terlihat di sini terdapat nilai rasa yang berbeda. Adapun konteks dari kutipan tersebut saat Markoni membuka usaha jasa rental alat musik, kebetulan orang-orang dari Belantik menggunakan jasa tersebut. Akibat terlalu semangat bermain musik, alat musik milik Markoni mengalami kerusakan yang parah. Kata udik digunakan sebagai bentuk konotatif dari kata kurang sopan, bodoh, culun, norak dan kampungan.

\section{Kata konkret}

Kata konkret memiliki makna secara langsung, apa adanya. Manfaat dari kata konkret adalah untuk memperjelas penggambaran suasana, peristiwa, kejadian, ataupun keadaan yang dilukiskan pengarang. Berikut ini adalah hasil temuan data beserta analisis kata konkret dalam novel Ayah karya Andrea Hirata.

Di sebelah radio dipajang vas bunga plastik berisi lima tangkai bunga mawar, juga dari plastik (Ayah, 2015:7).

Kutipan di atas menggambarkan bahwa radio merupakan barang mewah di rumah Amirza. Radio tersebut diletakkan di tempat paling aman yaitu di atas lemari rendah berkaca. Di sebelahnya diletakkan vas bunga guna memberikan kesan estetis. Kata radio dalam kutipan tersebut memiliki arti benda yang dapat menerima siaran suara atau bunyi melalui udara. Jenisnya ada yang menggunakan listrik dan ada yang menggunakan batu baterai. Dalam hal ini radio merupakan suatu benda yang jelas yang dapat dilihat bentuk maupun wujudnya.

Kosakata bahasa daerah 
Kosakata bahasa daerah dapat berasal dari berbagai daerah dari wilayah Indonesia, seperti Jawa, Sunda, Minang, Toraja, Melayu dan sebagainya. Adapun pemanfaatan kosakata dari bahasa daerah mengandung makna tertentu terutama untuk mencapai efek estetis. Hal yang mendasarinya adalah pengarang memilih kosakata tertentu dikarenakan kandungan falsasah nilai sehingga tidak dapat digantikan dengan diksi yang lain. Berikut ini adalah hasil temuan data beserta analisis kosakata bahasa daerah dalam novel Ayah karya Andrea Hirata.

“Tidak Pak Cik...maksud Pak Cik?” (Ayah, 2015:46).

Kata Pak Cik di dalam kutipan novel tersebut merujuk pada sebutan Bapak/Paman yaitu Syarif Miskin. Di dalam lema bahasa Indonesia tidak ditemukan kata Pak Cik yang merujuk pada pengertian ayah. Kata yang tersedia adalah Bapak atau Ayah. Sehingga kata Pak Cik termasuk dalam kosakata bahasa daerah yang berasal dari Melayu. Kutipan di atas merupakan gambaran pada saat Amiru menemui Syarif Miskin untuk mendapatkan penjelasan tentang kandang bebek dan jernihnya suara radio, Syarif Miskin menganggap Amiru belum cukup paham apabila ia jelaskan. Syarif Miskin mencoba menggunakan kata-kata yang mudah dipahami hingga Amiru bertanya padanya.

\section{Kata serapan}

Pengertian dari kata serapan adalah kata yang diambil atau dipungut dari bahasa lain, baik bahasa asing maupun bahasa daerah yang telah mengalami adaptasi struktur, tulisan dan lafal, maupun tidak diadaptasi dan sudah dikategorikan sebagai kosakata Bahasa Indonesia. Berikut ini adalah hasil temuan data beserta analisis kata serapan dalam novel Ayah.

Dalam kaitan-kaitan itu, secara aneh, Amiru selalu mendukung eksperimen ayahnya ... (Ayah, 2015:15).

Kata eksperimen dalam kutipan di atas terdapat dalam lema bahasa Indonesia. Kata tersebut berasal dari bahasa Inggris dengan bentuk experiment yang merujuk pada suatu percobaan yang bersistem dan berencana (untuk membuktikan kebenaran suatu teori dan sebagainya) dalam bahasa Indonesia. 


\section{Kata asing}

Kata asing yaitu kata yang berasal dari selain Bahasa Indonesia dan belum diserap ke dalam Bahasa Indonesia. Otomatis belum termuat dalam daftar Kamus Besar Bahasa Indonesia. Berikut ini adalah hasil temuan data beserta analisis kata asing dalam novel Ayah karya Andrea Hirata.

Volare (Ayah, 2015:22).

Kutipan di atas merupakan salah satu judul bab yang unik. Dalam bahasa Italia makna dari volare adalah terbang, yang menerbangkan. Kata tersebut termasuk ke dalam kata bahasa asing karena belum diserap ke dalam bahasa Indonesia karena tidak terdapat dalam lema bahasa Indonesia. Tujuan pengarang menggunakan kata ini sebagai unsur yang membuat unik dalam novel ini. Data ini menunjukkan kata asing yang berasal dari bahasa Italia.

Dia memandang sesuatu yang menyenangkan di sebelah sana, tersenyum, lalu seseorang memotretnya, candid (Ayah, 2015:233).

Kata candid dalam kutipan di atas merupakan kata asing dari bahasa Inggris karena kosakata tersebut tidak terdapat dalam lema bahasa Indonesia. Candid dalam bahasa Indonesia merujuk pada pengertian alami, asli dengan segala hal yang tidak dibuat-buat. Konteks dalam kutipan di atas saat Manikam memandangi foto yang dikirimkan oleh sepupu Zul dari Toboali. Sepupu Zul ingin mengenalkan Lena kepada Manikam melalui sebuah foto. Lena dalam foto tersebut tidak bergaya, tidak berdandan, tidak pula mengenakan baju bagus. Pandangannya ke arah sesuatu yang menyenangkan bukan kamera dan seseorang mengambil fotonya.

Hasil analisis penggunaan diksi yang dimanfaatkan Andrea Hirata dalam novel Ayah melukiskan peristiwa, kejadian, keadaan yang dilukiskan dengan menggunakan pilihan kata kata variatif yang ditandai dengan jenis-jenis diksi yang digunakan. Secara ringkas, penggunaan diksi dalam nove Ayah dapat dilihat pada tabel 1. 
Tabel 1. Penggunaan Diksi dalam Novel Ayah karya Andrea Hirata

\begin{tabular}{|c|c|c|c|c|c|}
\hline \multirow{2}{*}{ No } & \multirow{2}{*}{ Jenis Diksi } & \multicolumn{4}{|c|}{ Jumlah Penggunaan Diksi } \\
\hline & & $1-25$ & $26-50$ & $51-75$ & $76-100$ \\
\hline 1. & Kata Konotatif & 4 & & & \\
\hline 2. & Kata Konkret & 20 & & & \\
\hline 3. & Kosakata Bahasa Daerah & 6 & & & \\
\hline 4. & Kata Serapan & & & & 100 \\
\hline 5. & Kata Asing & 19 & & & \\
\hline
\end{tabular}

Berdasarkan tabel dan gambar 1 dapat disimpulkan bahwa Andrea Hirata banyak memanfaatkan kata serapan yang ditemukan sebanyak 100 data dari 149 jumlah data keseluruhan yang ditemukan. Adapun penggunaan jenis diksi yang lain meliputi kata konotatif berjumlah 4 data, kata konkret sebanyak 20 data, kosakata bahasa daerah 6 data, dan kata asing sebanyak 19 data. Apabila dilihat dari perbandingan serta persebarannya, Andrea Hirata cukup kreatif dalam mengkombinasikan jenis-jenis diksi tersebut untuk disajikan sebagai suatu karya sastra bervariasi baru. Adapun dominasi penggunaan kata serapan yang digunakan dilatarbelakangi oleh tingkat pendidikan Andrea Hirata dan juga riset yang dilakukan sebelum menuliskan novel Ayah ini.

\section{Nilai Pendidikan Karakter dalam Novel Ayah Karya Andrea Hirata}

Pendidikan karakter memiliki makna lebih tinggi dari pendidikan moral, karena pendidikan karakter tidak hanya berkaitan dengan masalah benar salah, tetapi bagaimana menanamkan kebiasaan (habit) tentang hal-hal yang baik dalam kehidupan sehingga anak/peserta didik memiliki kesadaran, dan pemahaman yang tinggi, serta kepedulian dan komitmen untuk menerapkan kebajikan dalam kehidupan sehari-hari (Mulyasa, 2012:3). Pembahasan poin kedua ini mengenai nilai-nilai pendidikan karakter yang berjumlah 18 poin versi kemendiknas seperti, religius, jujur, toleransi, (4) disiplin, (5) kerja keras, (6) kreatif, (7) mandiri, (8) demokrasi, (9) rasa ingin tahu, 10) semangat kebangsaan, 11) cinta tanah air, 12) menghargai prestasi, 13) bersahabat/komunikatif, 14) cinta damai, dan 15) gemar membaca, 16) peduli lingkungan, 17) peduli sosial, dan 18) tanggung jawab. 
Nilai pendidikan karakter merupakan salah satu daya tarik keterbacaan sebuah novel. Novel Ayah karya Andrea Hirata sangat sarat akan nilai-nilai pendidikan yang mampu membangun karakter para pembaca sekalian. Implementasi dari nilai pendidikan karakter dapat diketahui melalui diksi dan amanat dari setiap peristiwa yang dilukiskan dalam novel Ayah. Hasil annalisis nilai pendidikan karakter yang ingin disampaikan Andrea Hirata dalam novel Ayah yang paling menonjol adalah nilai religius dan kerja keras.

\section{Religius}

Sikap dan perilaku yang patuh dalam melaksanakan ajaran agama ang dianutnya, toleran terhadap pelaksanaan ibadah agama lain, dan hidup rukun dengan pemeluk agama lain. Secara tidak langsung nilai religius memperlihatkan hubungan manusia dengan Tuhan. Bagaimana cara berbakti kepada Tuhan, menjalankan perintahNya semampunya dan menjauhi segala laranganNya. Sikap ini dapat tercermin dari kegiatan beribadah, berdoa, memiliki sifat religius yang kuat. Hasil analisis nilai religius dalam novel Ayah karya Andrea Hirata seperti kutipan berikut.

...menggandengnya ke masjid, mengajarinya berpuasa dan mengaji.. (Ayah, 2015:183).

Dalam kutipan tersebut nilai religius digambarkan secara tersurat yaitu dengan menggandengnya ke masjid, mengajarinya berpuasa dan mengaji. Sabari sebagai seorang ayah (orang tua) wajib mengajarkan ilmu agama kepada anaknya yang direpresentasikan dengan menggandeng Zorro ke masjid, mengajarinya berpuasa, dan mengaji. Hal-hal yang diajarkan Sabari tersebut merupakan ajaran agama Islam yang merupakan contoh dari nilai pendidikan karakter religius.

\section{Kerja keras}

Definisi dari kerja keras yaitu perilaku yang menunjukkan upaya sungguh-sungguh dalam mengatasi berbagai hambatan belajar dan tugas, serta menyelesaikan tugas dengan sebaik-baiknya. Perilaku tersebut ditandai dengan berusaha sekuat tenaga, semangat dan juga pantang menyerah. 
Berikut ini adalah hasil temuan data beserta analisis nilai pendidikan karakter kerja keras dalam novel Ayah karya Andrea Hirata.

Meski kakinya perih dan napasnya tersengal-sengal, meski sampai finis malam nanti, Sabari bertekad untuk terus berlari karena dia teringat akan anaknya. Dia tak mau menyerah demi Zorro (Ayah, 2015:373).

Pada kutipan di atas menjelaskan saat malam telah tiba. Sabari masih terus berlari dnegan telapak kaki yang melepuh, berdarah. Seorang ayah tidak boleh menyerah demi anaknya seperti itulah kata hati Sabari. Nilai pendidikan karakter kerja keras yang disiratkan dalam kutipan tersebut ditandai dengan adanya tekad kuat Sabari untuk tetep berlari demi anaknya.

Muatan nilai pendidikan karakter dalam novel Ayah karya Andrea Hirata mencerminkan bahwa pengarang melalui karyanya ingin memotivasi pembaca untuk meneladani nilai-nilai pendidikan karakter. Secara keseluruhan hasil analisis dari nilai pendidikan karakter dalam novel Ayah karya Andrea Hirata dapat dilihat pada tabel 2 .

Tabel 2. Nilai Pendidikan Karater dalam Novel Ayah

\begin{tabular}{llcc}
\hline No & Nilai Pendidikan Karakter & \multicolumn{2}{c}{ Jumlah Data yang Muncul } \\
\cline { 2 - 3 } & & $1-10$ & $11-20$ \\
\hline 1. & Religius & 3 & 18 \\
\hline 2. & Jujur & 1 & \\
\hline 3. & Toleransi & 2 & 17 \\
\hline 4. & Disiplin & & \\
\hline 5. & Kerja Keras & 4 \\
\hline 6. & Kreatif & 5 \\
\hline 7. & Mandiri & 0 \\
\hline 8. & Demokrasi & 4 \\
\hline 9. & Rasa Ingin Tahu & 2 \\
\hline 10. & Semangat Kebangsaan & 4 \\
\hline 11. & Cinta Tanah Air & 6 \\
\hline 12. & Menghargai Prestasi & 5 \\
\hline 13. & Bersahabat/Komunikatif & 5 \\
\hline 14. & Cinta Damai & 9 \\
\hline 15. & Gemar Membaca & 0 \\
\hline 16. & Peduli Lingkungan & 6 \\
\hline 17. & Peduli Sosial & 6 \\
\hline 18. & Tanggung Jawab & \\
\hline
\end{tabular}


Nilai pendidikan karakter yang paling dominan adalah nilai religius dengan 18 data yang ditemukan, prosentasenya sebesar 19\% dan nilai kerja keras dengan prosentase $18 \%$ jumlah data yang ditemukan yaitu 17 buah. Dari kedelapan belas nilai pendidikan karakter yang sama sekali tidak muncul adalah nilai demokrasi dan nilai peduli lingkungan. Untuk nilai pendidikan karakter yang lain frekuensinya rata-rata yang muncul mulai dari 1-9 data.

Relevansi Novel Ayah Karya Andrea Hirata dengan Pembelajaran Bahasa dan Sastra Indonesia di SMK

Novel Ayah karya Andrea Hirata memiliki relevansi dengan pembelajaran bahasa dan sastra Indonesia khususnya pada pembelajaran apresiasi sastra. Ditinjau dari segi isi cerita yang diangkat dalam novel ini bertema kasih sayang seorang ayah terhadap anaknya. Novel ini dapat dijadikan sebagai materi ajar karena mengandung nilai-nilai pendidikan karakter yang dapat dijadikan sebagai upaya penanaman dan pembentukan karakter peserta didik. Selain itu novel juga dapat dijadikan sebagai materi ajar yang sesuai dengan kompetensi dasar dalam silabus SMA/SMK/MA kurikulum 2013 edisi revisi 2016. Berdasarkan wawancara dengan ahli sastra, ahli bahasa dan juga guru yang mengemukakan bahwa novel Ayah karya Andrea Hirata cocok/sesuai/relevan apabila dijadikan sebagai materi ajar dalam pembelajaran bahasa Indonesia di SMK khususnya pada apresiasi sastra. Hal ini sejalan dengan Kompetensi Dasar 3.11. dan 4.11. mengenai yaitu menganalisis pesan dari satu buku fiksi yang dibaca dan menyusun ulasan terhadap pesan dari satu buku fiksi yang dibaca. Kompetensi

\section{SIMPULAN}

Berdasarkan hasil penelitian dan pembahasan analisis terhadap novel Ayah karya Andrea Hirata diperoleh simpulan sebagai berikut. Pertama, novel Ayah karya Andrea Hirata pemanfaatan diksi yang digunakan oleh Andrea Hirata meliputi kata konotatif, kata konkret, kosakata bahasa daerah, kata serapan, dan kata asing. Temuan data yang paling banyak terdapat pada kata serapan dengan prosentase $67 \%$, jumlah datanya 100 data dari 149 temuan. Adapun prosentase 
kata konotatif 3\% dengan 4 temuan data, kata konkret 13\% dengan 20 temuan data, kosakata bahasa daerah $4 \%$ dengan 6 variasi data dan kata asing $13 \%$ dengan 19 temuan data. Kedua, nilai-nilai pendidikan karakter yang termuat dalam novel Ayah karya Andrea Hirata sebanyak 16 dari 18 butri nilai pendidikan karakter versi kemendiknas 2010. Nilai pendidikan karakter yang paling dominan yaitu nilai religius, jumlah temuan 18 dari keseluruhan data sebanyak 97, dengan prosentase $19 \%$. Adapun nilai pendidikan karakter yang banyak ditemukan selain itu adalah nilai kerja keras dengan prosentase 17\%. Demokratis dan nilai peduli lingkungan adalah dua butir nilai yang tidak dimunculkan dalam novel Ayah karya Andrea Hirata. Ketiga, relevansi hasil penelitian yang ditemukan tentang aspek diksi serta nilai pendidkan karakter dapat digunakan sebagai salah satu materi pembelajaran bahasa dan sastra Indonesia khususnya apreasiasi sastra. Pembelajaran yang berkaitan dengan buku fiksi (novel) yaitu kelas XI semester II dengan Kompetensi Dasar yang sesuai yaitu K.D. 3.11. dan 4.11. yang dapat dilengkapi dengan K.D. 3.20. dan 4.20. Isi dari Kompetensi Dasar 3.11 dan 4.11. adalah menganalisis pesan dari satu buku fiksi yang dibaca, menyusun ulasan terhadap pesan dari satu buku fiksi yang dibaca.

\section{DAFTAR PUSTAKA}

Al-Ma'ruf, A. I. (2009). Kajian Stilistika Novel Trilogi Ronggeng Dukuh Paruk Karya Ahmad Tohari: Perspektif Kritik Holistik. Surakarta.

Fatmalinda, L., Siswanto, W., \& Priyatni, E. T. (2016). Stilistika dalam Novel Ayah Karya Andrea Hirata. Jurnal Pendidikan, 993-995.

Hirata, A. (2015). Ayah. Yogyakarta: PT Bentang Pustaka.

Ismawati, E. (2013). Pengajaran Sastra. Yogyakarta: Penerbit Ombak.

Keraf, G. (2004). Diksi dan Gaya Bahasa. Jakarta: PT Gramedia Pustaka Utama.

.Nurgiyantoro, B. (2013). Teori Pengkajian Fiksi. Yogyakarta: Gajah Mada University Press.

Nurhayati. (2013). Apresiasi Prosa Fiksi Indonesia. Surakarta: Cakrawala Media.

Pusvita, W. D. (2017). Nilai-Nilai Pendidikan Karakter Pada Novel Ayah Karya Andrea Hirata. Leksema Vol 2 No 1 Januari-Juni 2017, 51-63. 
Rahmanto, B. (1988). Metode Pengajaran Sastra. Yogyakarta: Penerbit Kanisius.

Ratna, N. K. (2016). Stilistika Kajian Puitika Bahasa, Sastra, dan Budaya. Yogyakarta: Pustaka Pelajar.

Sangidu. (2004). Penelitian Sastra: Pendekatan, Teori, Metode, Teknik, dan Kiat. Yogyakarta: Unit Penerbitan Sastra Asia Barat. Fakultas Ilmu Budaya. Universitas Gadjah Mada.

Suwandi, S.(2011). Semantik:Pengantar Kajian Makna. Yogyakarta: Media Perkasa. 